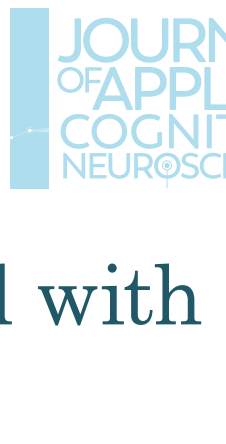

\title{
Neuropsychological evaluations associated with workplace accidents: a systematic review
}

DOI: https://doi.org/10.17981/JACN.1.1.2020.01

Carlos Antonio Vargas-María ${ }^{1}$

${ }^{1}$ Universidad Libre.

Barranquilla (Colombia)

Correspondence:

Carlos Vargas-Maria

Universidad Libre.

Barranquilla (Colombia)

E mail: cavama64@hotmail.com

\section{Abstract}

Most occupational accidents are evidenced by a loss of worker control over the procedures they carry out. Objective: To establish the neuropsychological tests used to assess the cognitive profile of workers as a measure to prevent workplace accidents. Method: An advanced and manual systematic search of databases (PubMed / MedLine, Web of Science, Scopus, Science Direct, Cochrane Library) was performed to evaluate the neuropsychological tests used in work settings. Results: The systematic review yielded 1777 articles, of which 150 were pre-selected according to what was reported in the abstract and 57 validated for complete reading. 21 articles were used for the narrative synthesis with a sample of two thousand eight hundred and fifty-four $(2,854)$ subjects; and a range of 18 to 60 years. Conclusion: The limited number of investigations that establish the neuropsychological profiles associated with occupational accidents are evident.

Keywords: Systematic Review; Neuropsychological Evaluation; Occupational Accident; Cognitive processes

\section{Evaluaciones neuropsicológicas asociadas con accidentes en el lugar de trabajo: una revisión sistemática}

\section{Resumen}

Los accidentes laborales en su gran mayoría se evidencian por una pérdida del control del trabajador sobre los procedimientos que desarrolla. Objetivo: Establecer las pruebas neuropsicológicas utilizadas para evaluar el perfil cognitivo de los trabajadores como medida de prevención de la accidentalidad laboral. Método: Se realizó una búsqueda sistemática avanzada y manual en bases de datos (PubMed/ MedLine, Web of Science, Scopus, Science Direct, Cochrane Library) para evaluar las pruebas neuropsicológicas utilizadas en ambientes laborales. Resultados: La revisión sistemática arrojó 1777 artículos, de los cuales 150 fueron pre-seleccionados de acuerdo a lo reportado en el resumen y 57 validados para su lectura completa. Se utilizaron 21 artículos para la síntesis narrativa con una muestra de dos mil ochocientos cincuenta y cuatro (2.854) sujetos; y un rango de 18 a 60 años. Conclusión: Sevidencian el limitado número de investigaciones que relacionan el establecimiento de perfiles neuropsicológicos asociados a la accidentalidad laboral.

Palabras clave: Revisión Sistemática; Evaluación Neuropsicológica; Accidentalidad laboral; Procesos cognitivos 


\section{INTRODUCTION}

Occupational accidents are defined as a series of bodily or tissue damage, which can trigger the decrease or loss of either total or partial functions in any part of the body (Niza, Silva \& Lima, 2018). In Colombia it is defined as "Sudden event that occurs due to or on the occasion of work, and that produces in the worker an organic injury, a functional or psychiatric disorder, disability or death" (Law 1562, 2012, art. 3); these accidents are characterized mainly due to the production of human suffering and economic losses at different levels of society (Nag \& Patel, 1998).

There are different approaches to workplace accidents that allow us to explain their nature. The first is organizational; this approach refers to the process of social construction of risk, where resources, labor and work overload are taken into account (Clarke \& Short, 1993). The second approach is the theory of human error, where the worker loses control over procedures due to insufficient training, stress, or fatigue (Jackson, 1995).

Occupational accidents can be attributed to immediate or basic causes, the immediate ones are generated directly, that is, by unsafe acts or inappropriate behaviors of workers in relation to the unsafe conditions of the facilities, infrastructure, equipment and tools that put at risk security (González, Bonilla, Reyes \& Chavarro, 2016). On the other hand, the basic causes give rise to the immediate ones and are made up of personal and work factors, which, in control, could be factors that reduce the impact of the immediate causes (Chinchilla, 2002). Personal factors play a fundamental role in the motivation, suitability, and knowledge of safety standards by the worker (Huamán, 2017). Work-relat- ed causes refer to training workers in the use of machines and materials that comply with occupational health standards, optimal structural conditions with the legal extension of working hours and the establishment of organizational systems that can demonstrate the commitment of companies with the safety of their employees (Ortega, 2017).

Data provided by the International Labor Organization (ILO, 2019) suggest that workplace accidents cause around 380,000 deaths per year and 374,000,000 non-fatal accidents or injuries in the world. In Colombia, the Ministry of Labor (Mintrabajo, 2018) ensures that occupational accidents correspond on average to $7.2 \%$ of the population affiliated with the general occupational risk system, for that same year there were 483,560 non-fatal accidents or injuries in the workplace and 410 deaths. According to the previously reported figures, it is important to take into account that occupational accidents increase significantly according to the nature of the work, especially those that are called high risk. The Ministry of Social Protection of Colombia (Ley 2090, 2003) defines the High-risk work activities such as those in which the work or the place where they are performed represents a decrease in healthy life expectancy and a greater exposure or intensity compared to other work activities. Among those considered high-risk jobs are mining or those that involve performance in tunnels or underground, exposure to high temperatures, ionizing radiation, proven carcinogenic chemicals and in units of military forces, civil aeronautics, or similar entities.

Occupational accidents have different implications in relation to the parties, Feng, Zhang and Wu (2015) establish the 
subject, the family, society and companies as the focus of involvement. The social implications refer to the deployment of the necessary resources to attend to the accident through legal and health channels. For their part, companies go through financial losses, the temporary or permanent absence of the worker and the intangible costs of accidents (Ascuénaga, 2006). Family implications are non-material losses, in case of non-fatal accidents resulting in disability. The family must adapt to the new situation and take care of the worker who has suffered the accident, assumed by an external health assistant or internally by a family member (Navarrete \& Zicavo, 2007). Overload in responsibilities and delicacy in care tasks can trigger burnout syndrome in the caregiver, manifesting symptoms associated with stress and anxiety (Caraguay, 2018).

Cognitive functions facilitate adaptation to the worker or subject to the environment and allow them to develop an active role (Dorado, 2012). These functions are linked to the level of performance, and a failure in any of them can be a predictor of an occupational accident, these failures are usually registered as human error, one of the main approaches in occupational accidents (Wadsworth, Simpson, Moss \& Smith, 2003). Knowledge of this relationship seeks to promote health in the workplace as the main method of preventing this type of error. Behavior-based safety programs are currently being used which seek to reinforce safe behaviors in individuals so that they are maintained over time (Meliá, 2007). Neuropsychological evaluation is the tool that allows establishing an accurate diagnosis of the state of cognitive functions, establishing the necessary limits to objectify the neuropsychological profiles of the pathologies that may have been triggers of occupational accidents (Mauri, Paletta, Colasanti, Miserocchi y Altamura, 2014).

Based on these positions, neuroscience has sought to improve the training of workers in behavior-based safety since the 1990s. One of the most recognized is the "SafeStart" project created by Larry Wilson, which seeks to avoid Work accidents focusing on the control that the worker may have over the relationship of the environment and their own body, this project establishes four causes of most work accidents: fatigue, haste, frustration and complacency, these alter attention and can generate loss of balance, traction or grip and leave the worker on the line of fire (Ciaffoni, 2019).

On the other hand, the National Institute of Health and Safety at Work (INSST, 2018) offers companies the prevention program FPSICO 4.0 that allows identifying the working conditions that present a psychosocial risk for workers, this method evaluates the time work, autonomy, work capacity, psychological demands, variety of work, supervision, interest, performance, and social support relationships. In the evaluation of psychological demands, this method assesses the cognitive demands, related to decision-making, memory, attention, and knowledge management required by the work being done; and the emotional demands that are produced by the work environment, work climate and the capacity for emotional control that a specific job requires (Aguilar-Soria, 2014).

Considering the importance of reducing the indicators of accidents at work and establishing the cognitive profiles that could increase these figures. The present review aims to establish the neuropsychological profiles associated with occupational accidents. 


\section{Methodology}

\section{Search strategy for the systematic review}

A database of original articles was developed, based on systematic searches of electronic sources. The following databases were searched: PubMed / MedLine, Web of Science (WOS), Scopus, Science Direct, and Cochrane Library. All studies published from 2009 to 2020 that assess the relationship between cognitive processes and occupational accidents were identified.

The search was limited to literature in English and Spanish, no other languages were included. With the use of Boolean intercession operators ("AND" and "Y"). A cross search was carried out with the following strings: 1) Work accident (Industrial accidents OR work accident); 2) Cognitive processes evaluated (Cognitive processes OR Attention OR Memory OR Cognitive Assessment).

\section{Criteria for Inclusion and Selection of Articles}

To be included in the review, the studies had to meet the following criteria:

\section{Participants: Adult between 18-60 years} old, and who did not present any neurocognitive, psychiatric or psychoactive substance abuse disorder.

\section{Labor relationship: Formal.}

3. Method: Use instruments for neuropsychological measurement of cognitive processes.

4. Results: Descriptive, correlational, or predictive analysis.

5. Type of study: research articles (quasiexperimental or experimental methods), excluding review articles, theoretical or single case studies and meta-analyzes.

\section{Qualitative Synthesis}

From the included studies, the results indicate the tests used to evaluate cognitive profiles associated with occupational accidents, as well as the cognitive functions that are frequently evaluated. The PRISMA statement17 (Figure 1) was followed to inform the items of this systematic review.

\section{RESULTS}

The findings of this review show the limited number of investigations that relate the establishment of neuropsychological profiles associated with occupational accidents. A separation of cognitive functions is seen in the different investigations, few establish a comprehensive profile as the object of study, some functions were evaluated in multiple investigations such as attention and memory, and others were evaluated in a lesser proportion such as cognitive flexibility and processing speed. It is important to point out that this review seeks to gather the greatest evidence that reflects the state of research and knowledge gaps in the study of the performance of cognitive functions in occupational accidents, since accidents in the workplace affect many spheres of work-business and personal life, implying a high financial and social cost.

In the assessment of cognitive functions in the workplace, no specific neuropsychological batteries were found to be used consistently and uniformly for this purpose. On the other hand, tests and scales were found that are used to measure cognitive functions in different work environments such as aviation (Asmayawati \& Nixon, 2020), military activities (Frings, 2011; Irgens-Hansen et al., 2015; Smith et al., 2019, Bell, Virden, Lewis \& Cassidy, 2015), conduction (Horrey, Lesch \& Garabet, 2009; 
Articles initially selected in public ations identified in the databases PubMed / Medline, Web of Science, Scopus, Science Direct, Cochrane Librarv): with the following strings: 1. Occupational accident: (Industrial accidents $O R$ work accident); 2. Cognitive processes evaluated: (Cognitive processes OR Attention OR Memorv OR Cognitive Assessment $)$. $(n=1777)$

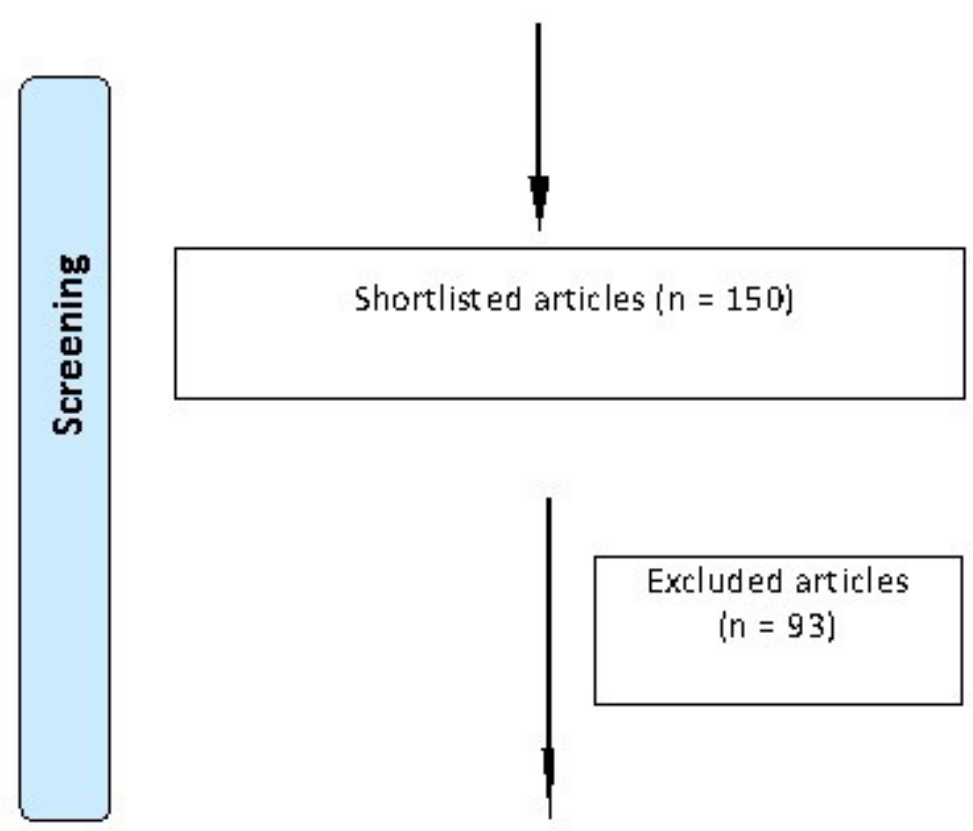

Excluded articles: theoretical articles, articles that report traffic accidents or industrial accidents of an environmental nature, articles reporting after work accidents and their neurocognitive sequelae in those affected, articles that do not report neuropsychological evaluation or that the cognitive function thev report was not systematically evaluated.
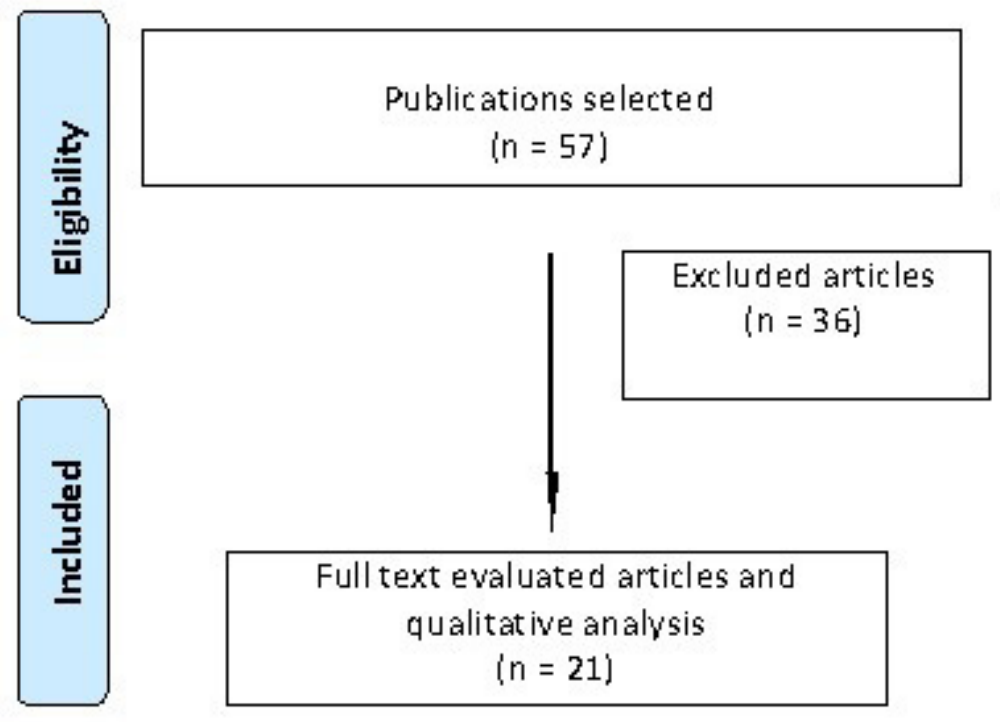

Excluded by:

The sample does not meet the inclusion criteria: there is no emplovment relationship, the workers are under 18 vears of age or older adults ladvanced age decreases cognitive functions to a certain degree, there is no normative neurocognitive development in the sample, or the selected sample includes clinical pictures.

The type of articles: review articles, evaluate environmental factors in accidents, there is no relation ship with occupational accident s, or the objective is to validate a test.

There is no neuropsychological evaluation: thev do not report a neuropsvchological evaluation, questionnaires are applied to the sample and no objective tests.

Figure 1. Prism Flow Diagram.

Source: Authors.

Cheng, Ting, Liu \& Ba, 2015; De Oliveira et al., 2020; Chen, Chou, Su \& Wen, 2019, Di Nocera et al., 2018, Adrian, Postal, Moessinger, Rascle \& Charles, 2011; Elfer- ing, Grebner \& Haller, 2012), construction (Brossoit et al., 2019), service sector (Roll, Siu, Li \& De Witte, 2019; Elfering, Grebner \& De Tribolet-Hardy, 2013), industrial 
operators and services (Kodappully, Srinivasan \& Srinivasan, 2016; Muller et al., 2012) and other activities (Buodo, Patron, Benvenuti \& Palomba, 2018; Askaripoor et al., 2019; Petitta, Probst, Ghezzi \& Barbaranelli, 2019; Huang, Menozzi \& Favey, 2019).

One of the most widely used scales is the Cognitive Failure Scale in the Workplace (WCFS) developed by Wallace and Chen (2005) that was used by different investigations (Petitta et al., 2019; Elfering et al., 2012; Elfering et al., 2013) this questionnaire assesses memory, attention, inhibition and praxis. On the other hand, Di Nocera, Ferlazzo and D'Olimpio (2014) propose a questionnaire of cognitive errors based on attention, which was used by Di Nocera et al. (2018). In this same line of cognitive questionnaires Wadsworth et al. (2005) report the Cognitive Failures Questionnaire.

However, the aforementioned investigations use short scales and even ecological assessments. On the other hand, some authors report the use of neuropsychological tests (Horrey et al., 2009; Adrian et al., 2011; Muller et al., 2012; Cheng et al., 2015; Irgens-Hansen et al., 2015; Buodo et al., 2018; Askaripoor et al., 2019; Chen et al., 2019; Smith et al., 2019; De Oliveira et al., 2020).

\section{Literature search}

The systematic cross-search of the two chains showed 1777 articles, of which 150 were pre-selected according to what was reported in the abstract and 57 validated for their complete reading (Figure 1). Among the articles included there are 10 experimental articles with descriptive analysis, 4 experimental with analysis of correlational scope, 4 quasi-experimental with correlational analysis, 2 experimental with linear regression analysis, 1 quasi-experimental article with analysis of descriptive scope.

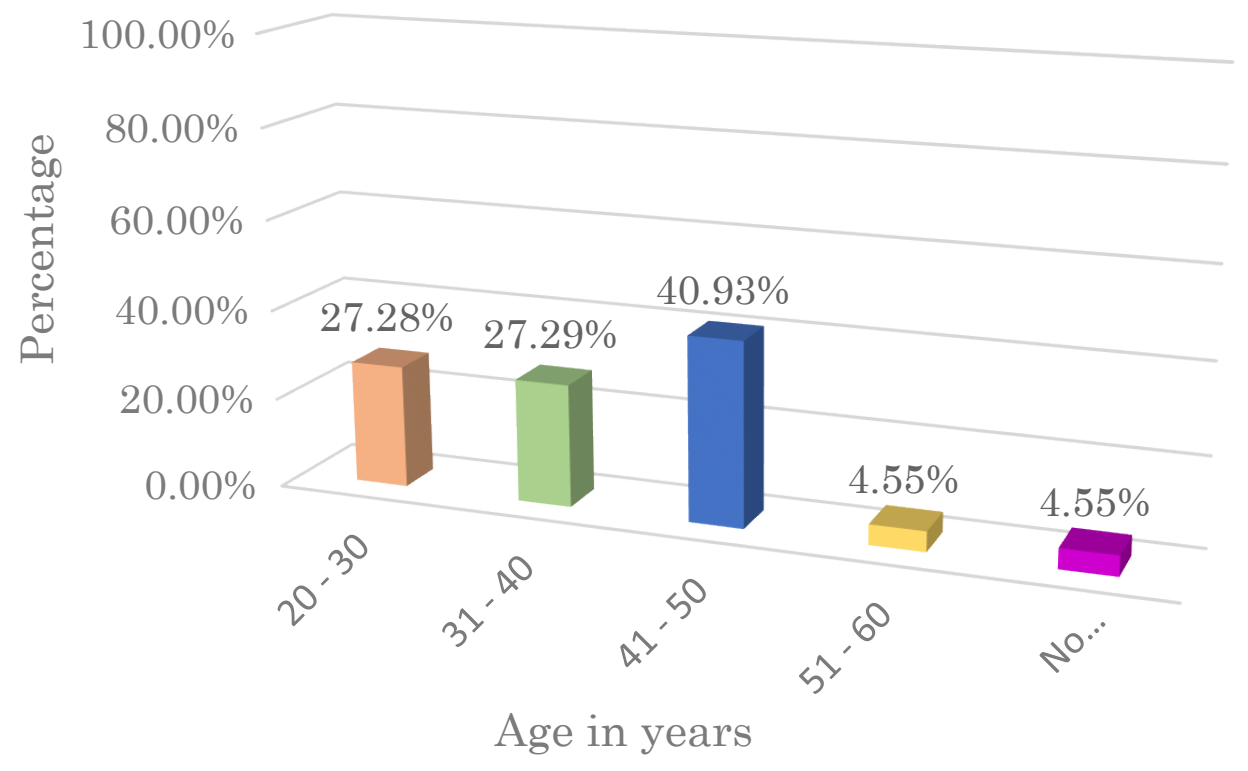

Figure 2. Age distribution.

Source: Authors. 


\section{Characteristics of the included articles}

In the systematic review, 21 articles were used with a sample of two thousand eight hundred fifty-four $(2,854)$ subjects; and a range of 18 to 60 years, this range was different for each article, the most frequent ages of the subjects ranged between 31 and 50 years. As evidenced in Figure 2.

A quantitative and qualitative synthesis of the 21 articles included was developed and descriptive variables were analyzed. Since no unified data were found on the performances in the subtests of the neuropsychological tests used in each investigation. It should be noted that more than $50 \%$ of the articles included are from 2018 onwards. On the other hand, an important participation of the USA, the United Kingdom and Switzerland is observed in the work of the variables analyzed.
According to what was found, this set of neuropsychological tests, questionnaires, and scales to evaluate cognitive functions in correlation with occupational accident rates is evidenced (Table 1).

\section{Discussion}

This review includes 21 articles, which report one or more cognitive functions evaluated by different types of questionnaires or neuropsychological tests. The findings of this review show the limited number of investigations that relate the establishment of neuropsychological profiles associated with occupational accidents. Unified evaluations are evidenced and few establish a comprehensive profile as an object of study, some cognitive functions most evaluated in reported investigations were attention and memory (Buodo et al., 2018; Asmayawati \& Nixon, 2020;

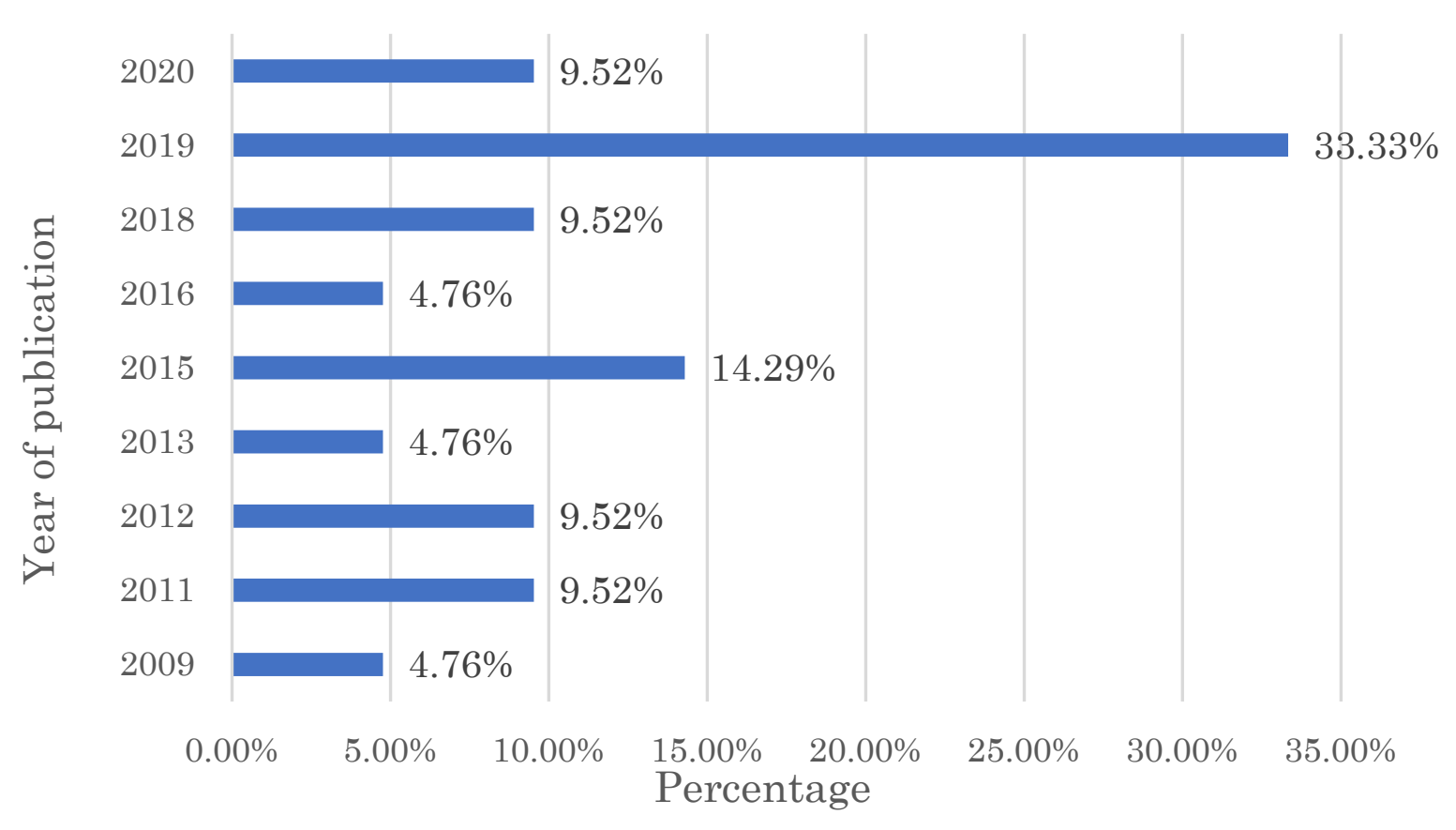

Figure 3. Distribution of articles by publication date.

Source: Authors. 


\begin{tabular}{|c|c|c|c|}
\hline Authors & Year & Measuring instrument & Evaluated functions \\
\hline $\begin{array}{l}\text { Buodo, Patron, Benvenuti and } \\
\text { Palomba. }\end{array}$ & 2018 & $\begin{array}{l}\text { Trail Making Test (TMT; Reitan, 1958; Italian adaptation by Giovagnoli et al., 1996). } \\
\text { Test d2 (Brickencamp \& Zillmer, 1998). }\end{array}$ & $\begin{array}{l}\text { Executive functions. } \\
\text { Attention. } \\
\text { Visual perceptual skills. }\end{array}$ \\
\hline Asmayawati and Nixon. & 2020 & Critical Decision Method Interview (MDL) (Klein, Calderwood \& MacGregor, 1989). & $\begin{array}{l}\text { Decision making. } \\
\text { Problem solving }\end{array}$ \\
\hline Frings. & 2011 & Troubleshooting test (8 items extracted from Luchins \& Luchins, 1969). & $\begin{array}{l}\text { Decision making. } \\
\text { Cognitive flexibility. }\end{array}$ \\
\hline Cheng, Ting, Liu and Ba. & 2015 & EGG-IGT (Simulated decision making). & $\begin{array}{l}\text { Impulsiveness and Decision } \\
\text { Making. }\end{array}$ \\
\hline \multirow{4}{*}{$\begin{array}{l}\text { De Oliveira, Barroso, Leopoldo, } \\
\text { Gouvea, Castaldelli-Maia and } \\
\text { Leyton. }\end{array}$} & \multirow{4}{*}{2020} & The sustained attention test (TACOM-B) (Tonglet, 2007). & Sustained attention. \\
\hline & & $\begin{array}{l}\text { The Trace Color Test (CTT) comprises two forms (CTT1 and CTT2) (Santana et al., } \\
\text { 2010). }\end{array}$ & Interference, divided attention. \\
\hline & & Test D2 (Brickenkamp, Zillmer \& Balcar, 2000). & Sustained attention. \\
\hline & & Stroop (Stroop, 1931). & Interference, divided attention. \\
\hline Chen, Chou, Su and Wen. & 2019 & Attention-Related Driving Error Scale (ARDES) (Nucciarone, Poó, Tosi \& Montes, 2012). & Attention. \\
\hline $\begin{array}{l}\text { Brossoit, Crain, Leslie, } \\
\text { Hammer,Truxillo and Bodner. }\end{array}$ & 2019 & Workplace Cognitive Failure Scale (WCFS) (Broadbent et al., 1982). & Memory and Attention. \\
\hline Huang, Menozzi and Favey. & 2019 & Test for screening visual skills (Huang et al., 2019). & Attention. \\
\hline Roll, Siu, Li and De Witte. & 2019 & Attention scale related to cognitive error (Cheyne, Carriere \& Smilek, 2006). & Attention. \\
\hline \multirow{3}{*}{$\begin{array}{l}\text { Smith, Cooper, Merullo, Cohen, } \\
\text { Heaton, Claro and Smith. }\end{array}$} & \multirow{3}{*}{2019} & $\begin{array}{l}\text { task GO/NO GO (GNG), Automated NeuropsychologicalAssessment Metrics (ANAM4, } \\
\text { version 4). }\end{array}$ & $\begin{array}{l}\text { Sustained attention and } \\
\text { Inhibición. }\end{array}$ \\
\hline & & Visual task-backtrack, Automated NeuropsychologicalAssessment (ANAM4, version 4). & Attention. \\
\hline & & $\begin{array}{l}\text { Visual task adjustment - backtrack adapted measure of attention and working memory } \\
\text { (Angelet, 2015). }\end{array}$ & Working memory. \\
\hline $\begin{array}{l}\text { Petitta, Probst, Ghezzi and } \\
\text { Barbaranelli. }\end{array}$ & 2019 & Cognitive Failure Scale in the Workplace (CFQ) (Wallace \& Chen, 2005). & Memory and Attention. \\
\hline $\begin{array}{l}\text { Askaripoor, Motamedzade, } \\
\text { Golmohammadi, Farhadian, } \\
\text { Babamiri and Samavati. }\end{array}$ & 2019 & Three-minute visual task GO/NO GO. & Divided attention. \\
\hline $\begin{array}{l}\text { Di Nocera, Ricciardi, Longo, } \\
\text { Mastrangelo, Cutini and Bisaglia. }\end{array}$ & 2018 & Workplace Cognitive Failure Scale (WCFS) (Broadbent et al., 1982). & Attention. \\
\hline $\begin{array}{l}\text { Kodappully, Srinivasan and } \\
\text { Srinivasan. }\end{array}$ & 2016 & Eye tracking applications. & $\begin{array}{l}\text { Attention, Inhibition and } \\
\text { working memory. }\end{array}$ \\
\hline
\end{tabular}




$\frac{\text { Authors }}{\text { Irgens-Hansen, Gundersen, Sunde, }}$

Baste, Harris, Bråtveit and Moen.

Bell, Virden, Lewis and Cassidy.

Elfering, Grebner and De TriboletHardy.

Elfering, Grebner and Haller.

Muller, Gunstad, Alosco, Miller, Updegraff, Spitznagel and Glickman.

Adrian, Postal, Moessinger, Rascle and Charles.

2011

Trail Making Test A y B (Reitan, 1958).

Stroop (Stroop, 1931).

Incompatibility test (Zimmermannand \& Fimm, 1994).

The go / no-go test (Zimmermann \& Fimm, 1994).

Task plus-minus (Jersild, 1927).

Flexibility test (Zimmermann \& Fimm, 1994).

Letters and Numbers Task (Rogers \& Monsell, 1995).

Letter memory task (Morris \& Jones, 1990).

Operation interval task (Turner \& Engle, 1989).

Sequence of numbers and letters (Wechsler, 2000).

Bourdon-Wiersma test (Grewel, 1953).

WAIS III Encoding Subtest (Wechsler, 2000).

Block design (Wechsler, 2000).

Search for symbols (Wechsler, 2000).

Paced auditory serial addition task (PASAT) (Brookhuis, De Vries \& De Waard, 1991;

Horrey,Lesch and Garabet.

2009

Patten, Kircher, Östlund \& Nilsson, 2004).

Guessing Task, Based on the Twenty Questions Quiz (TQT; Bruner, Olver, Greenfield \& Rigney, 1966, Kafer \& Hunter, 1997).

Evaluated functions

Response time, precision, and

inhibition.

Reaction time and attention.

Cognitive performance.

Memory and Attention.

Memory and Attention.

Memory and Attention.

Executive functions.

Reaction time.

Spatial memory.

Verbal interference: Inhibition of responses.

Inhibition.

Visual attention.

Inhibition.

Shifting.

Cognitive flexibility.

Working memory.

Sustained attention and

Inhibition.

Working memory.

Working memory.

Working memory.

Attention.

coding.

Viso-special and visoconstructive skills.

Processing speed.

Working memory and

Attention.

Decision making. 
Chen et al., 2019; Brossoit et al., 2019; Roll et al., 2019; Petitta et al., 2019; Askaripoor et al., 2019; Di Nocera et al., 2018; Kodappully et al., 2016; Irgens et al., 2015; Bell et al., 2015; Elfering et al., 2012; 2013; Muller et al., 2012; Horrey et al., 2009) were evaluated to a lesser extent as cognitive flexibility and processing speed (Frings, 2011; Bell et al., 2015; Muller et al., 2012; Adrian et al., 2011). It is important to point out that this review seeks to gather the greatest evidence that reflects the state of research and knowledge gaps in the study of the performance of cognitive functions in occupational accidents, since accidents in the workplace affect many spheres of work-business and personal life, implying a high financial and social cost (Feng et al., 2015).

In the evaluation of cognitive functions in the workplace, no neuropsychological batteries established specifically for this purpose were found, the tests and scales used to measure specific functions are diverse and there is no established relationship with a neuropsychological battery that can cover comprehensively the set of cognitive functions. One of the most widely used scales is the Cognitive Failure in the Workplace Scale (CFQ) (Broadbent, Cooper, FitzGerald \& Parkes, 1982) which, in accordance with the above, assesses memory, attention, inhibition, and praxis, the first two being the most studied.

Despite the limited number of investigations, it has been shown that many of the work accidents are due to cognitive failures and that these can arise in the operationalization of the work environment (Almirall, 2001). The evidence presented may be useful for researchers and developers of strategies and / or training on safety and health at work to comprehensively evaluate cognitive functions and the direct implications that these have on worker behavior (DíazCabrera et al., 2008).
The limitations in this study respond to the scarce scientific production on the incidence of the functioning of cognitive functions in occupational accidents, a limited number of databases were accessed for the collection of information and few studies were found with an approach / approach comprehensive of cognitive functions. Likewise, the articles included worked with small samples and their results are not conclusive enough to be extrapolated and faithfully represent the reality of the phenomena. Half of the articles included have a descriptive scope, meaning a low level of evidence. However, these information gaps represent an opportunity for new research, with cognitive functions being a crucial variable in worker performance and in the design of studies or projects aimed at increasing safety in the workplace and thus reducing accidents.

\section{REFERENCIAS}

Adrian, J., Postal, V., Moessinger, M., Rascle, N. \& Charles, A. (2011). Personality traits and executive functions related to on-road driving performance among older drivers. Accident Analysis \& Prevention, 43(5), 1652-1659. https:// doi.org/10.1016/j.aap.2011.03.023

Aguilar-Soria, J. A. (2014). Evaluación de riesgos psicosociales. [Tesis pregrado]. Universidad de Jaén, Andalucía España. Disponible en https://hdl.handle. net/10953.1/464

Almirall, P. (2001). Ergonomía cognitiva: apuntes para su aplicación en trabajo y salud. La Habana: Ministerio de Salud Pública, Instituto Nacional de Salud de los Trabajadores. Recuperado de http://www.sld.cu/galerias/ pdf/sitios/insat/ergonomia_cognitiva._apuntes_para_su_aplicacion_en_ trabajo_y_salud.pdf 
ANAM4. (version 4). Automated NeuropsychologicalAssessment Metrics. [Library of computer-based assessments]. Norman: Centro para el Estudio del Rendimiento del Operador (C-SHOP).

Angelet, A. (2015). Compartir memòries. on thew@terfront,36(1), 13-14.Available: https://www.raco.cat/index.php/Waterfront/article/view/291691/380185

Askaripoor, T., Motamedzade, M., Golmohammadi, R., Farhadian, M., Babamiri, M. \& Samavati, M. (2019). Effects of light intervention on alertness and mental performance during the post-lunch dip: a multi-measure study. Industrial health, 57(4), 511-524. https://doi.org/10.2486/indhealth.2018-0030

Asmayawati, S. \& Nixon, J. (2020). Modelling and supporting flight crew decision-making during aircraft engine malfunctions: developing design recommendations from cognitive work analysis. Applied Ergonomics, 82, 102953. https://doi.org/10.1016/j.apergo.2019.102953

Azcuénaga, L. M. A. (2006). Manual práctico para la investigación de accidentes e incidentes laborales. Madrid: FC Editorial.

Bell, L., Virden, T., Lewis, D. \& Cassidy, B. (2015). Efects of 13-Hour 20-Minute Work Shi s on Law Enforcement Officers' Sleep, Cognitive Abilities, Health, Quality of Life, and Work Performance: The Phoenix Study. Police Quarterly, 18(3), 293-337. https://doi. org/10.1177/1098611115584910

Brickenkamp, R. \& Zillmer, E. (1998). D2Test of attention. Seatle: Hogrefe \& Huber.

Brickenkamp, R., Zillmer, E. \& Balcar, K. (2000). Test pozornosti d2. Praha: Hogrefe-Tescentrum sro.
Broadbent, D. E., Cooper, P. F., FitzGerald, P. \& Parkes, K. R. (1982). The cognitive failures questionnaire (CFQ) and its correlates. British journal of clinical psychology, 21(1), 1-16. https://doi. org/10.1111/j.2044-8260.1982.tb01421.x Brookhuis, K. A., De Vries, G. \& De Waard, D. (1991). The effects of mobile telephoning on driving performance. Accident Analysis \& Prevention, 23(4), 309-316. https://doi.org/10.1016/00014575(91)90008-S

Brossoit, R. M., Crain, T. L., Leslie, J. J., Hammer, L. B., Truxillo, D. M. \& Bodner, T. E. (2019). The effects of sleep on workplace cognitive failure and safety. Journal of Occupational Health Psychology, 24(4), 411-422. https://doi. org/10.1037/ocp0000139

Bruner, J. S., Olver, R., Greenfield, P. M. \& Rigney, J. R. (1966). Studies in cognitive growth. New York: Wiley.

Buodo, G., Patron, E., Benvenuti, S. M. \& Palomba, D. (2018). Single-session attention bias modification training in victims of work-related accidents. Frontiers in Psychology, (9), 1-9. https://doi. org/10.3389/fpsyg.2018.01619

Caraguay, B. M. (2018). Síndrome de burnout en las personas cuidadoras y su influencia en la calidad de vida del usuario discapacitado. [Tesis magistral]. Universidad Regional Autónoma de los Andes, Quevedo, Ecuador. Disponible en http://dspace.uniandes.edu.ec/handle/123456789/7961

Chen, H. K., Chou, H. W., Su, J. W. \& Wen, F. H. (2019). Structural interrelationships of safety climate, stress, inattention and aberrant driving behavior for bus drivers in Taiwan. Transportation research part A: policy and practice, 130, 118-133. https://doi.org/10.1016/j. tra.2019.09.007 
Cheng, A. S., Ting, K. H., Liu, K. P. \& Ba, Y. (2015). Impulsivity and risky decision making among taxi drivers in Hong Kong: an event-related potential study. Accident Analysis \& Prevention, 95(Part B), 387-394. https:// doi.org/10.1016/j.aap.2015.12.021

Cheyne, J. A., Carriere, J. S. \& Smilek, D. (2006). Absent-mindedness: Lapses of conscious awareness and everyday cognitive failures. Consciousness and cognition, 15(3), 578-592. https://doi. org/10.1016/j.concog.2005.11.009

Chinchilla, R. (2002). Salud y seguridad en el trabajo. Costa Rica: EUNED.

Ciaffoni, A. (2019). Safe Start, su seguro de vida inicial. [Tesis de pregrado]. Universidad Militar Nueva Granada, Bogotá, D.C., Colombia. Disponible en http://hdl.handle.net/10654/21181

Clarke, L. \& Short, J. F. (1993). Social organization and risk: some current controversies. Annual Review of Sociology, 19(1), 375-399. https://doi.org/10.1146/ annurev.so.19.080193.002111

De Oliveira, L. G., Barroso, L. P., Leopoldo, K., Gouvea, M. J. C., CastaldelliMaia, J. \& Leyton, V. (2020). Driving under the influence of psychostimulant drugs: Effects on cognitive functioning among truck drivers in Brazil. Transportation research part $F$ : traffic psychology and behaviour, 68, 336-347. https://doi.org/10.1016/j. trf.2019.11.018

Di Nocera, F., Ricciardi, O., Longo, E., Mastrangelo, S., Cutini, M. \& Bisaglia, C. (2018). Attentional Control in Accidents Involving Agricultural Tractor Operators. Ergonomics in Design: The Quaterly of Human Factors Applications, 26(1), 17-23. https://doi. org/10.1177/1064804617737444
Di Nocera, F., Ferlazzo, F. \& D’Olimpio, F. (2014). Is 'error proneness' specific to errors? Predictive validity of the cognitive failures questionnaire. International Journal of Human Factors and Ergonomics, 3(2), 208-225. https://doi. org/10.1504/IJHFE.2014.067843

Díaz-Cabrera, D., Isla-Díaz, R.. RoloGonzález, G., Villegas-Velásquez, O., Ramos-Sapena, Y. y Hernández-Fernaud, E. (2008). La salud y la seguridad organizacional desde una perspectiva integradora. Papeles del Psicólogo, 29(1), 83-91. Recuperado de http:// www.papelesdelpsicologo.es/pdf/1541. pdf

Dinges, D. F., Mallis, M. M., Maislin, G. \& Powell, J. W. (1998). Evaluation of techniques for ocular measurement as an index of fatigue and as the basis for alertness management. [DOTHS-808-762]. Springfield: National Highway Traffic Safety Administration. Available: https://rosap.ntl.bts. gov/view/dot/2518

Dorado, C. (2012). Funciones cognitivas del cerebelo: implicación en las funciones ejecutivas. Revista Chilena de Neuropsicología, 7(2), 48-53. https://doi. org/10.5839/rcnp.2012.0702.02

DuBois, A. B., Harb, Z. F. \& Fox, S. H. (1990). Thermal discomfort of respiratory protective devices. American Industrial Hygiene Association journal, 51(10), 550-554. https://doi. org/10.1080/15298669091370086

Elfering, A., Grebner, S. \& De TriboletHardy, F. (2013). The long arm of time pressure at work: Cognitive failure and commuting near-accidents. European Journal of Work and Organizational Psychology, 22(6), 737-749. https://doi. org/10.1080/1359432X.2012.704155 
Elfering, A., Grebner, S. \& Haller, M. (2012). Railway-controller-perceived mental work load, cognitive failure and risky commuting. Ergonomics, 55(12), 14631475. https://doi.org/10.1080/00140139. 2012.718802

E-Prime. (version 2.0). Experiment generation and data collection. [Software]. Extracted from https://pstnet.com/ products/e-prime-legacy-versions/

Feng, Y., Zhang, S. \& Wu, P. (2015). Factors influencing workplace accident costs of building projects. Safety science, 72, 97-104. https://doi. org/10.1016/j.ssci.2014.08.008

Frings, D. (2011). The effects of group monitoring on fatigue-related einstellung during mathematical problem solving. Journal of Experimental Psychology: Applied, 17(4), 371-381. https://doi.org/10.1037/a0025131

Giovagnoli, A., Del Pesce, M., Mascheroni, S., Simoncelli, M., Laiacona, M. \& Capitani, E. (1996). Trail making test: normative values from 287 normal adult controls. The Italian journal of neurological sciences, 17(4), 305-309. https://doi.org/10.1007/ BF01997792

Golden, C. J. \& Freshwater, S. M. (2002). Stroop Color and Word Test Kit for Adults. Quezon City: Stoelting.

González, A., Bonilla, J., Reyes, C. \& Chavarro, A. (2016). Analysis of the causes and consequences of accidents occurring in two constructions projects. Revista Ingeniería de Construcción, 31(1), 5-16. http://dx.doi.org/10.4067/S071850732016000100001

Grewel, F. (1953). Le test de Bourdon-Wiersma [The Bourdon-Wiersma test]. Folia Psychiatrica, neurologica et neurochirurgica Neerlandica, 56(5), 694-703.
Horrey, W., Lesch, M. \& Garabet, A. (2009). Dissociation between driving performance and drivers' subjective estimates of performance and workload in dual-task conditions. Journal of Safety Research, 40(1), 7-12. https:// doi.org/10.1016/j.jsr.2008.10.011

Huamán, M. (2017). Implementación de un sistema de gestión de seguridad y salud ocupacional para disminuir los incidentes y accidentes laborales de los trabajadores de la Empresa R\&W Constructora y Servicios Generales, Lima 2017. [Tesis profesional]. Universidad César Vallejo, Lima, Perú. Disponible en https://hdl.handle. net/20.500.12692/12149

Huang, Y. Y., Menozzi, M. \& Favey, C. (2019). A screening tool for occupations requiring a high level of attentional performance. International Journal of Industrial Ergonomics, 72, 86-92. https://doi.org/10.1016/j.ergon.2019.04.005

ILO. (2019). Investigación de accidentes del trabajo a través del método del árbol de causas. [Manual de formación para investigadores]. Santiago de Chile: OIT. Recuperado de https://www.ilo.org/wcmsp5/groups/public/---americas/---rolima/---sro-santiago/documents/publication/wcms_717401.pdf

INSST. (2018). F-PSICO. Factores Psicosociales. (Versión 4.0). [Método de evaluación]. Recuperado de https://cutt.ly/ St5cdEa

Irgens-hansen, K., Gundersen, H., Sunde, E., Baste, V., Harris, A., Bråtveit, M. \& Moen, B. E. (2015). Noise exposure and cognitive performance: A study on personnel on board Royal Norwegian Navy vessels. Noise Health, 17(78), 320-327. https://doi.org/10.4103/14631741.165057 
Jackson, D. (1995). Marine Environmental Safety, Risk Assessment, and Management Practice: a Life-Table with Co-variates Approach to the Survival Analysis of Vessel Losses and Casualties. Washington, D.C.: American Sociological Association.

Jersild, A. T. (1927). Mental set and shift. Archives of psychology. Archives of Psychology, (89), 1-81.

Kafer, K. L. \& Hunter, M. (1997). On testing the face validity of planning/ problem-solving tasks in a normal population. Journal of the International Neuropsychological Society, 3(2), 108-119. https://doi.org/10.1017/ S1355617797001082

Klein, G. A., Calderwood, R. \& Macgregor, D. (1989). Critical decision method for eliciting knowledge. IEEE Transactions on systems, man, and cybernetics, 19(3), 462-472. https://doi. org/10.1109/21.31053

Kodappully, M., Srinivasan, B. \& Srinivasan, R. (2016). Towards predicting human error: Eye gaze analysis for identification of cognitive steps performed by control room operators. Journal of Loss Prevention in the Process Industries, 42, 35-46. https:// doi.org/10.1016/j.jlp.2015.07.001

Luchins, A. S. \& Luchins, E. H. (1969). Einstellung effect and group problem solving. The Journal of Social Psychology, 77(1), 79-89. https://doi.org/1 0.1080/00224545.1969.9919848

Mauri, M. C., Paletta, S., Colasanti, A., Miserocchi, G. y Altamura, A. C. (2014). Correlaciones clínicas y neuropsicológicas de la depresión mayor después de una lesión cerebral postraumática, un estudio prospectivo. Revista asiática de psiquiatría, 12, 118-124.
Meliá, J. L. (2007). Seguridad basada en el comportamiento. En, G. Nogareda, J. Martínez, J. Peiró, A. Duro, M. Salanova y M. Lahera, Perspectivas de Intervención en Riesgos Psicosociales: Medidas Preventivas (pp. 157-180). Barcelona: Foment del Treball Nacional y Fundación Nacional para la Prevención de Riesgos Laborales.

Morris, N. \& Jones, D. M. (1990). Memory updating in working memory: The role of the central executive. British journal of psychology, 81(2), 111-121. https:// doi.org/10.1111/j.2044-8295.1990. tb02349.x

Muller, M. D., Gunstad, J., Alosco, M. L., Miller, L. A., Updegraff, J., Spitznagel, M. B. \& Glickman, E. (2012). Acute cold exposure and cognitive function: evidence for sustained impairment. Ergonomics, 55(7), 792-798. https:// doi.org/10.1080/00140139.2012.66549 7

Nag, P. K. \& Patel, V. G. (1998). Work accidents among shiftworkers in industry. International Journal of Industrial Ergonomics, 21(3-4), 275-281. https:// doi.org/10.1016/S0169-8141(97)000504

Navarrete, C. C. y Zicavo, M. N. (2007). Consecuencias en la dinámica familair: Discapacidad permanente del (a) jefe (a) de hogar, por accidente laboral: impacto en la funcionalidad familiar. En, J. Vírseda y J. Bezanilla, Enfermedad y Familia (Vol. II, pp. 59-84). Toluca: UNAM.

Niza, C., Silva, S. \& Lima, M. L. (2008). Occupational accident experience: Association with workers' accident explanation and definition. Safety science, 46(6), 959-971. https://doi. org/10.1016/j.ssci.2007.11.015 
Nucciarone, M. I., Poó, F. M., Tosi, J. D. \& Montes, S. A. (2012). La inatención como factor de riesgo en conductores de moto. Temas em Psicologia, 20(2), 479-490. https://dx.doi.org/10.9788/ TP2012.2-15

Ortega, J. (2017). Importancia de la seguridad de los trabajadores en el cumplimiento de procesos, procedimientos y funciones. Academia \& Derecho, (14), 155-175. https:// doi.org/10.18041/2215-8944/academia.14.1490

Patten, C. J., Kircher, A., Östlund, J. \& Nilsson, L. (2004). Using mobile telephones: cognitive workload and attention resource allocation. Accident analysis \& prevention, 36(3), 341350. https://doi.org/10.1016/S00014575(03)00014-9

Paúl, C. (2005). Envelhecer em Portugal: Psicologia, saúde e prestação de cuidados. Lisboa: Climepsi Editores.

Petitta, L., Probst, T. M., Ghezzi, V. \& Barbaranelli, C. (2019). Cognitive failures in response to emotional contagion: their effects on workplace accidents. Accident Analysis \& Prevention, 125, 165-173. https://doi.org/10.1016/j. aap.2019.01.018

Reitan, R. M. (1958). Validity of the Trail Making Test as an indicator of organic brain damage. Perceptual and motor skills, 8(3), 271-276. https://journals. sagepub.com/doi/abs/10.2466/pms.195 8.8.3.271? journalCode $=$ pmsb

República de Colombia. Congreso de la República. (11 de julio de 2012). Por el cual se modifica el sistema de riesgos laborales y se dictan otras disposiciones en materia de salud. [Ley 1562]. Diario Oficial: 48.488. Recuperado de https://n9.cl/yifg
República de Colombia. Ministerio de la Protección Social. (26 de julio de 2003). Por el cual se definen las actividades de alto riesgo para la salud del trabajador y se modifican y señalan las condiciones, requisitos y beneficios del régimen de pensiones de los trabajadores que laboran en dichas actividades. [Decreto <ley> 2090]. Diario Oficial: 45.262. Recuperado de https://n9.cl/pkr8b

República de Colombia. MinTrabajo. (Noviembre 23, 2018). MinTrabajo avanza en la modificación de los Estándares Mínimos de seguridad y salud para las pequeñas y medianas empresas. [Online]. Disponible en https:// n9.cl/z1h9v

Rogers, R. D. \& Monsell, S. (1995). Costs of a predictible switch between simple cognitive tasks. Journal of experimental psychology: General, 124(2), 207231. Available from https://psycnet. apa.org/buy/1995-31890-001

Roll, L. C., Siu, O. L., Li, S. Y. \& De Witte, H. (2019). Human error: the impact of job insecurity on attention-related cognitive errors and error detection. International journal of environmental research and public health, 16(13), 1-61. https://doi.org/10.3390/ijerph16132427

Santana, I., Pacanaro, S., Rossetti, M., Almeida, I., Ribeiro, N., Marchi, C., Correa, E. \& Souza, M. C. (2010). Color Trails Test: a Brazilian normative sample. Psychology \& Neuroscience, 3(1), 93-99. https://doi.org/10.3922/j. psns.2010.1.012

Smith, C. D., Cooper, A. D., Merullo, D. J., Cohen, B. S., Heaton, K. J., Claro, P. J. \& Smith, T. (2019). Sleep restriction and cognitive load affect performance on a simulated marksmanship task. Journal of sleep research, 28(3), e12637. https://doi.org/10.1111/jsr.12637 
Stroop, R. C. (1931). U.S. Patent No. 1,823,069. Washington, DC: U.S. Patent and Trademark Office.

Tonglet, E. (2007). Tonglet Battery For Drivers' Mental Evaluation (2 ed.). São Paulo: Vetor Editora.

Turner, M. \& Engle, R. (1989). Is working memory capacity task dependent? Journal of memory and language, 28(2), 127-154. https://doi.org/10.1016/0749596X(89)90040-5

Wadsworth, E. J. K., Simpson, S. A., Moss, S. C. \& Smith, A. P. (2003). The Bristol Stress and Health Study: accidents, minor injuries and cognitive failures at work. Occupational Medicine, 53(6), 392-397. https://doi.org/10.1093/ occmed/kgg088

Wallace, J. C. \& Chen, G. (2005). Development and validation of a job-specific measure of cognitive failure: Implications for occupational safety. Journal of Occupational and Organizational Psychology, 78(4), 615-632. https://doi. org/10.1348/096317905X37442

Wechsler, D. (2000). Wechsler Adult Intelligence Scale. [Manual for the Wechsler Adult Intelligence Scale-Third edition]. San Antonio: The Psychological Corporation.

Zimmermann, P. \& Fimm, B. (1994). Batteria di Test per l'Esame dell'Attenzione (TEA). Roma: Erre.
Carlos Antonio Vargas María: Physician, aspiring $\mathrm{PhD}$ in applied cognitive neuroscience; Master in Psychoneurpschiatry and rehabilitation, Specialist in occupational medicine, member of the GIINCO group, research line: Neuroscience and health (University de la Costa, Colombia). 